\title{
Investing in Malaysian healthcare using technique for order preference by similarity to ideal solution
}

\author{
Farah Waheeda Azhar ${ }^{1}$, Zati Halwani Abd Rahim¹, Norasyikin Abdullah Fahami², \\ Siti Khatijah Nor Abdul Rahim ${ }^{3}$, Hilwana Abd Karim ${ }^{4}$ \\ ${ }^{1}$ Department of Mathematics, Faculty of Computer and Mathematical Sciences, Universiti Teknologi MARA, Perak, Malaysia \\ ${ }^{2}$ Department of Business Management, Faculty of Business and Management, Universiti Teknologi MARA, Perak, Malaysia \\ ${ }^{3}$ Department of Computer Science, Faculty of Computer and Mathematical Sciences, Universiti Teknologi MARA, Selangor, \\ Malaysia \\ ${ }^{4}$ Department of Business Management, Faculty of Business and Management, Universiti Teknologi MARA, Negeri Sembilan, Malaysia
}

\begin{tabular}{|c|c|}
\hline Article Info & ABSTRACT \\
\hline Article history: & The purpose of this research is to assess the financial performance of \\
\hline Received Jul 10, 2021 & $\begin{array}{l}\text { Malaysian Healthcare companies using the multi-criteria and decision- } \\
\text { making method. namely technique for order preference by similarity to ideal }\end{array}$ \\
\hline Revised Dec 13, 2021 & solution (TOPSIS). The financial data of 20 companies in 2019 are retrieved \\
\hline Accepted Jan 11, 2022 & $\begin{array}{l}\text { from Datastream. For many years, ratios of financial aspects have been } \\
\text { employed to analyse the companies' financial performance. However, some }\end{array}$ \\
\hline Keywords: & $\begin{array}{l}\text { studies indicate that the traditional ratio analysis is insufficient to measure a } \\
\text { firm's financial performance. Thus, this paper employs the technique for }\end{array}$ \\
\hline Decision making & order preference by similarity to ideal solution, or simply TOPSIS, to gain a \\
\hline Financial ratio & $\begin{array}{l}\text { more comprehensive result. The TOPSIS approach involves seven steps, } \\
\text { utilizing significant ratios in financial aspect such as debt ratio debt to }\end{array}$ \\
\hline Fuzzy TOPSIS & equity ratio, current ratio, return on equity (ROE), acid-test ratio, earnings \\
\hline Healthcare companies & per share (EPS), and return on asset (ROA), as the criteria to evaluate the \\
\hline Ranking & $\begin{array}{l}\text { companies' financial performances. The result of this study ranks } 20 \\
\text { healthcare companies in Malaysia and makes recommendations for } \\
\text { investment-worthy companies to the investors, allowing the maximization of } \\
\text { investment benefits. The results from this research are crucial for investors, } \\
\text { companies, market participants, public and private policymakers to enhance } \\
\text { their investment decision-making. }\end{array}$ \\
\hline
\end{tabular}

This is an open access article under the CC BY-SA license.

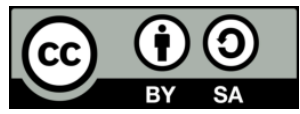

\section{Corresponding Author:}

Farah Waheeda Azhar

Department of Mathematics Faculty of Computer and Mathematical Sciences, Universiti Teknologi MARA Perak Branch, Tapah Campus, 35400 Tapah Road, Perak, Malaysia

Email: farah154@uitm.edu.my

\section{INTRODUCTION}

Investment refers to obtaining an asset with the intention that the asset will appreciate in value and grow over time. With that, wealth created can be used to fulfill many financial objectives such as giving extra income, saving up for retirement, paying debt and obligations, payment of tuition fees, purchase of other assets and so on. Historically, stock market investment has delivered wonderful returns over time. Moreover, over the long term, no other types of investment tend to perform better than stock investment. This was proven by one of the world's richest men, Warren Buffett, who had become rich through stock investing. However, being successful in the stock market is an extremely difficult task. The basic concept in stock investing is to find "cheap" or "undervalued" stocks and sell "rich" or "overvalued" stocks to get capital gain (profit). Most of the time, stock market investors need to conduct a fundamental and technical analysis to decide on which stocks to invest in. These kinds of evaluations require a lot of expertise and also consume a 
lot of time. However, investors can utilize a simple yet powerful decision technique named technique for order preference by similarity to ideal solution (TOPSIS) in making investment decisions. TOPSIS, which was proposed by [1], examines a number of alternatives according to a pre-specified criterion, identifies each criterion's weight, normalises each criterion's score, and between each alternative, it ultimately calculates the geometric distance and the ideal option, see also [2]-[7]. According to [8]-[13], financial ratios are crucial because they can be used to assess the competitive advantage and the level of companies' sustainability within industries. Relevant studies that utilised TOPSIS as the methodology can be seen in the paper by [14]-[23]. Whereas, studies by [24], [25] also adopted financial ratio analysis using TOPSIS to analyse the performances of the service and telecommunication industry in the Malaysia context. The fact that the TOPSIS method allows attributing weights to the level of importance of each criterion and at the same time considers the uncertainty, subjectivity, and complexity of the decision process lead the investors to rank companies from worst to the best. Healthcare companies in Malaysia can be defined as businesses related to medical services, manufacturers of medical equipment and drugs, or suppliers of healthcare to patients. According to ASEAN Briefing on October 6, 2020, Malaysian healthcare is expected to rise compared to other neighboring countries like Singapore and Thailand. This is due to Malaysia's healthcare system that has reached the world-class level-fueled by high-quality human resources. Bursa Malaysia has divided the country's healthcare sector into three sub-sectors, namely health care equipment and services (for example; Top Glove Corporation Berhad and Hartalega Holdings Berhad), health care providers (for instance; Kumpulan Perubatan Johor (KPJ Healthcare Berhad) and IHH Healthcare Berhad which was previously known as Integrated Healthcare Holdings Berhad) and pharmaceuticals like Pharmaniaga Holdings and Duopharma Biotech Berhad. All these companies are included in the data for this study.

Other previous researches which incorporate healthcare sectors in their studies are well documented in [24], [25]. However, there were no comprehensive studies on the application of the fuzzy TOPSIS method in evaluating the financial performance of Malaysian healthcare companies. Hence, the objective of this study is to propose a conceptual framework for evaluating, comparing, and ranking the financial performance of healthcare companies in Malaysia with the TOPSIS model. The remainder of this article is arranged in the following manner: Section 2 summarises the data and methodology used, followed by a discussion on the findings, and the final section concludes with recommendations for further research.

\section{RESEARCH METHODOLOGY}

Referring to Datastream, a set of data consisting of 20 Malaysian listed healthcare companies for the year 2020 was retrieve as represented in Table 1 . The 20 healthcare companies in the year 2020 were analyzed using the TOPSIS method based on seven types of ratios of the financial aspect. The financial ratios that are considered in this paper include current ratio, dividend yield, p/e ratio, gross profit margin, return on equity (ROE), total debt \% total asset, and earnings per share (EPS) to evaluate the companies' financial performances. Current ratio, dividend yield, gross profit margin, EPS, and ROE are the greatest ideal alternatives for maximising the criteria that need to be maximised, whilst total debt $\%$ total asset and P/E ratio need to be minimised.

Table 1. Healthcare Companies in Malaysia stock market

\begin{tabular}{lc}
\hline \multicolumn{1}{c}{ COMPANY } & CODE \\
\hline ADVENTA BHD & $\mathrm{C} 1$ \\
APEX HEALTHCARE BHD & $\mathrm{C} 2$ \\
CAREPLUS GROUP B & $\mathrm{C} 3$ \\
DUOPHAMA & $\mathrm{C} 4$ \\
HARTALEGA HOLDINGS & $\mathrm{C} 5$ \\
IHH HEALTHCARE & $\mathrm{C} 6$ \\
KOSSAN RUBBER & $\mathrm{C} 7$ \\
KOTRA INDUSTRIES BHD & $\mathrm{C} 8$ \\
KPJ HEALTHCARE BHD & $\mathrm{C} 9$ \\
LKL INTERNATIONAL & $\mathrm{C} 10$ \\
LYC HEALTHCARE BHD & $\mathrm{C} 11$ \\
MALAYSIAN GENOMICS & $\mathrm{C} 12$ \\
NOVA PHARMA SOL & $\mathrm{C} 13$ \\
OPTIMAX & $\mathrm{C} 14$ \\
PHARMANIAGA BERHAD & $\mathrm{C} 15$ \\
SMILELINK HEALTH & $\mathrm{C} 16$ \\
SUPERMAX CORP BHD & $\mathrm{C} 17$ \\
TMC LIFE SCIENCES & $\mathrm{C} 18$ \\
TOP GLOVE CORP & $\mathrm{C} 19$ \\
YSP SOUTHEAST ASIA & $\mathrm{C} 20$ \\
\hline
\end{tabular}


The TOPSIS method is designed to help with multi-criteria decision-making. The TOPSIS method takes the geometric distance between positive and negative ideal solutions into account. The TOPSIS method is broken down into seven steps as following and was performed in MS Excel:

- Step 1: Decision matrix $\left(\left(\mathrm{x}_{\mathrm{ij}}\right)_{\mathrm{m} \times \mathrm{n}}\right)$ formation. A decision matrix that consists of $\mathrm{m}$ alternatives (companies), and $\mathrm{n}$ criteria (financial ratio) is formed. Concerning each criterion, the score of each alternative is given as $\mathrm{x}_{\mathrm{ij}}$, and then a matrix $\left(\mathrm{x}_{\mathrm{ij}}\right)_{\mathrm{m} \times \mathrm{n}}$ is constructed as shown in (1).

$$
\left(x_{i j}\right)_{m \times n}=\left[\begin{array}{cccc}
x_{11} & x_{12} & \ldots & x_{1 n} \\
x_{21} & x_{22} & \ldots & x_{2 n} \\
\cdot & & & \cdot \\
\cdot & & & \cdot \\
\cdot & & & \cdot \\
x_{m 1} & x_{m 2} & \ldots & x_{m n}
\end{array}\right]
$$

- Step 2: Decision matrix normalization. Various attribute dimensions are transformed into nondimensional attributes, and a normalized decision matrix $R=\left(r_{i j}\right)_{m \times n}$ is constructed, as (2) and (3).

$$
\begin{gathered}
r_{i j}=\frac{x_{i j}}{\sqrt{\sum_{i=1}^{m} x_{i j}^{2}}}, i=1,2, \ldots, m, j=1,2, \ldots, n \\
R=\left(r_{i j}\right)_{m \times n}=\left[\begin{array}{cccc}
r_{11} & r_{12} & \ldots & r_{1 n} \\
r_{21} & r_{22} & \ldots & r_{2 n} \\
\cdot & & & \cdot \\
\cdot & & & \cdot \\
\cdot & & & \cdot \\
r_{m 1} & r_{m 2} & \ldots & r_{m n}
\end{array}\right]
\end{gathered}
$$

- $\quad$ Step 3: Weighted normalized decision matrix (T) Formation. The weighted normalized decision matrix is calculated in (4) and (5).

$T=\left(t_{i j}\right)_{m \times n}=\left(w_{j} r_{i j}\right)_{m \times n}, i=1,2, \ldots, m$ where $w_{j}=\frac{w_{j}}{\sum_{j=1}^{n} w_{j}}, j=1,2, \ldots, n$

$\sum_{j=1}^{n} w_{j}=1$ and $W_{j}$ is the original weight given to the indicator $w_{j}, j=1,2, \ldots, n$.

$$
\mathrm{T}=\left[\begin{array}{cccc}
\mathrm{w}_{1} \mathrm{r}_{11} & \mathrm{w}_{2} \mathrm{r}_{12} & \ldots & \mathrm{w}_{\mathrm{n}} \mathrm{r}_{1 \mathrm{n}} \\
\mathrm{w}_{1} \mathrm{r}_{21} & \mathrm{w}_{2} \mathrm{r}_{22} & \ldots & \mathrm{w}_{\mathrm{n}} \mathrm{r}_{2 \mathrm{n}} \\
\cdot & & & \cdot \\
\cdot & & & \cdot \\
\cdot & & & \cdot \\
\mathrm{w}_{1} \mathrm{r}_{\mathrm{m} 1} & \mathrm{w}_{2} \mathrm{r}_{\mathrm{m} 2} & \ldots & \mathrm{w}_{\mathrm{n}} \mathrm{r}_{\mathrm{mn}}
\end{array}\right]
$$

- $\quad$ Step 4: The positive/best ideal $\left(A_{b}\right)$ solution and the negative/worst ideal $\left(A_{w}\right)$ solution determination.

$$
\begin{aligned}
A_{b}= & \left\{\left\langle\min \left(t_{i j} \mid i=1,2, \ldots, m\right) \mid j \in J_{-}\right\rangle,\right. \\
& \left.\left\langle\max \left(t_{i j} \mid i=1,2, \ldots, m\right) \mid j \in J_{+}\right\rangle\right\} \equiv\left\{t_{b j} \mid j=1,2, \ldots, n\right\}, \\
A_{w}= & \left\{\left\langle\max \left(t_{i j} \mid i=1,2, \ldots, m\right) \mid j \in J_{-}\right\rangle,\right. \\
& \left.\left\langle\min \left(t_{i j} \mid i=1,2, \ldots, m\right) \mid j \in J_{+}\right\rangle\right\} \equiv\left\{t_{w j} \mid j=1,2, \ldots, n\right\},
\end{aligned}
$$

where,

$\mathrm{J}_{+}=\{\mathrm{j}=1,2, \ldots, \mathrm{n} \mid \mathrm{j}$ associates with the criteria having a positive impact, and $\mathrm{J}_{-}=\{\mathrm{j}=1,2, \ldots, \mathrm{n} \mid \mathrm{j}$ associates with the criteria having a negative impact.

- $\quad$ Step 5: The separation measures for each alternative from the best ideal solution and negative ideal solution calculation. The separation measures for each alternative are calculated in (8): 


$$
d_{i b}=\sqrt{\sum_{j=1}^{n}\left(t_{i j}-t_{b j}\right)^{2}}, i=1,2, \ldots, m
$$

The distance from the negative ideal solution is calculated in (9):

$$
d_{i w}=\sqrt{\sum_{j=1}^{n}\left(t_{i j}-t_{w j}\right)^{2}}, i=1,2, \ldots, m
$$

- $\quad$ Step 6: The relative closeness to the ideal solution for each alternative calculation: For each alternative, the relative closeness to the ideal solution $S_{\text {iw }}$ is computed asshown in (10).

$$
\mathrm{s}_{\mathrm{iw}}=\frac{\mathrm{d}_{\mathrm{iw}}}{\mathrm{d}_{\mathrm{ib}}+\mathrm{d}_{\mathrm{iw}}}, 0 \leq \mathrm{s}_{\mathrm{iw}} \leq 1, \mathrm{i}=1,2, \ldots, \mathrm{m}
$$

$s_{i w}=0$ if and only if the alternative solution has the worst condition whereas $s_{i w}=1$ if and only if the alternative solution has the best condition.

- Step 7: Rank the alternatives. The alternatives based on the relative closeness coefficient in $s_{\text {iw }}$ are ranked in descending order. The best alternative is the alternative with the highest $\mathrm{s}_{\mathrm{iw}}$.

\section{RESULTS AND DISCUSSION}

From the decision-making matrix shown in Table 2, the normalised decision matrix, and weighted normalised decision matrix were performed to get the positive ideal solution and the negative ideal solution for each decision criterion shown in Table 3. Using (8) and (9), Table 4 shows the distance of all options from the positive ideal solution $\left(\mathrm{D}_{\mathrm{IB}}\right)$ and the negative ideal solution $\left(\mathrm{D}_{\mathrm{IW}}\right)$. For each alternative, the relative closeness to the ideal solution, $\mathrm{s}_{\mathrm{iw}}$ is obtained using (10). Table 5 shows the relative closeness distance of each decision alternative to the ideal solution, $s_{\text {iw }}$. The companies' overall financial performance status is determined by their relative closeness distance to the ideal solution, $\mathrm{s}_{\mathrm{iw}}$, which is listed in descending order. The company with the highest $\mathrm{s}_{\mathrm{iw}}$ value is considered the greatest alternative, as it provides the best financial

\begin{tabular}{|c|c|c|c|c|c|c|c|}
\hline Company & $\begin{array}{l}\text { Current } \\
\text { Ratio }\end{array}$ & $\begin{array}{l}\text { Dividend } \\
\text { Yield }\end{array}$ & $\mathrm{P} / \mathrm{E}$ & $\begin{array}{l}\text { Gross Profit } \\
\text { Margin }\end{array}$ & $\begin{array}{c}\text { Return On Equity } \\
\text { (ROE) }\end{array}$ & $\begin{array}{c}\text { Total Debt \% } \\
\text { Total Assets }\end{array}$ & EPS \\
\hline $\mathrm{C} 1$ & 2.17 & 0 & -19.9 & -12.99 & -19.22 & 23.19 & -0.077 \\
\hline $\mathrm{C} 2$ & 2.82 & 1.05 & 29.89 & 21.21 & 12.55 & 4.48 & 0.118 \\
\hline C3 & 1.28 & 0.14 & 9.09 & 28.5 & 68.29 & 7 & 0.228 \\
\hline $\mathrm{C} 4$ & 3.06 & 1.63 & 39.95 & 40.92 & 9.99 & 28.89 & 0.085 \\
\hline C5 & 2.67 & 0.81 & 53.4 & 25.36 & 18.08 & 8.41 & 0.129 \\
\hline C6 & 1.31 & 0.73 & 242.5 & 20.27 & 0.9 & 31.26 & 0.023 \\
\hline C7 & 2.27 & 1 & 10.59 & 44.81 & 57.06 & 15.7 & 0.425 \\
\hline $\mathrm{C} 8$ & 2.65 & 3.01 & 14.25 & 66.12 & 16.33 & 13 & 0.204 \\
\hline C9 & 0.87 & 1.2 & 38.74 & 37.65 & 5.6 & 52.47 & 0.026 \\
\hline $\mathrm{C} 10$ & 3.41 & 0 & 35.43 & 34.32 & 7.37 & 14.28 & 0.01 \\
\hline C11 & 0.92 & 0 & -5.81 & 23.96 & -43.73 & 50.24 & -0.029 \\
\hline $\mathrm{C} 12$ & 11.12 & 0 & 2.09 & -636.61 & 130.6 & 0 & 0.165 \\
\hline C13 & 6.07 & 0.77 & 37.77 & 41.35 & -6.37 & 0.93 & -0.004 \\
\hline $\mathrm{C} 14$ & 2.68 & 0 & 47.56 & 68.9 & 16 & 31.53 & 0.025 \\
\hline $\mathrm{C} 15$ & 0.78 & 2.5 & 19.92 & 2.48 & 8.14 & 43.91 & 0.105 \\
\hline $\mathrm{C} 16$ & 2 & 0.57 & 54.1 & 47.27 & 2.87 & 19.4 & 0.004 \\
\hline $\mathrm{C} 17$ & 1.27 & 0 & 40.04 & 42.78 & 39.57 & 10.32 & 0.196 \\
\hline $\mathrm{C} 18$ & 2.66 & 0.26 & 14.54 & 9.05 & 2.08 & 9.3 & 0.009 \\
\hline C19 & 2.01 & 4.9 & 1.73 & 39.4 & 47.32 & 21.26 & 0.219 \\
\hline $\mathrm{C} 20$ & 4.76 & 3.07 & 2.38 & 42 & 6.55 & 12.78 & 0.157 \\
\hline
\end{tabular}
results.

Table 2. Multicriteria decision making matrix

The result in Table 5 indicates the ranking of the healthcare companies in all sectors. Tables 6-8 show the ranking result of the healthcare companies in equipment sectors, provider sectors, and pharmaceuticals in terms of their financial performances using the TOPSIS approach, respectively. Based on the tables, it is observed that Top Glove Corp steadily ranked first among all the healthcare sectors and healthcare equipment subsector. For that reason, Top Glove Corp is said to have the highest ranking in terms of financial performance. Apart from that, IHH healthcare, Kossan Rubber, Kotra Industries Bhd and 
Careplus Group Berhad are found to be among the top five companies for all healthcare sectors and within their own subsectors. It is not surprising that two out of five highest rank companies are medical glove producers (Top Glove Corp and Kossan Rubber) since there is a surge in demand for gloves worldwide that pushed their earnings to a record high. While IHH healthcare ranked high in all sectors, it is an international premium healthcare provider in many markets where the demand for quality care is strong and growing. On the other hand, the fact that Adventa Bhd, LYC healthcare Bhd and Nova Pharma SOL ranked lowest within their subsectors are confirmed as these companies also ranked lowest in all healthcare sectors.

Table 3. Positive ideal $\left(A_{b}\right)$ and negative ideal $\left(A_{w}\right)$ solutions

\begin{tabular}{cccccccc}
\hline Ideal Solution & $\begin{array}{c}\text { Current } \\
\text { Ratio }\end{array}$ & $\begin{array}{c}\text { Dividend } \\
\text { Yield }\end{array}$ & P/E & $\begin{array}{c}\text { Gross Profit } \\
\text { Margin }\end{array}$ & $\begin{array}{c}\text { Return on } \\
\text { equity (ROE) }\end{array}$ & $\begin{array}{c}\text { Total Debt } \% \\
\text { Total Assets }\end{array}$ & EPS \\
\hline $\begin{array}{c}\text { Positive ideal } \\
\text { solution }\left(A_{b}\right)\end{array}$ & 0.09704323 & 0.092604908 & 0.124645797 & 0.014974696 & 0.1034922 & 0.067727814 & 0.088473355 \\
$\begin{array}{c}\text { Negative ideal } \\
\text { solution }\left(A_{w}\right)\end{array}$ & 0.006807 & 0 & -0.01022867 & -0.138360541 & -0.03465 & 0 & -0.01602929 \\
\hline
\end{tabular}

Table 4. Distance of the alternatives from the positive ideal solution $\left(d_{i b}\right)$ and negative ideal solution $\left(d_{i w}\right)$

\begin{tabular}{ccc}
\hline Company Name & $d_{i b}$ & $d_{i w}$ \\
\hline C1 & 0.244189293 & 0.140679621 \\
C2 & 0.198149969 & 0.159613572 \\
C3 & 0.193654773 & 0.182035692 \\
C4 & 0.186316025 & 0.16827092 \\
C5 & 0.189556027 & 0.164259138 \\
C6 & 0.178796152 & 0.205176172 \\
C7 & 0.176869785 & 0.201037281 \\
C8 & 0.18280053 & 0.181949963 \\
C9 & 0.201537164 & 0.171677889 \\
C10 & 0.209564162 & 0.157817814 \\
C11 & 0.246798051 & 0.158022142 \\
C12 & 0.234251672 & 0.172894267 \\
C13 & 0.208150127 & 0.16137485 \\
C14 & 0.199880208 & 0.171279151 \\
C15 & 0.193581976 & 0.168171819 \\
C16 & 0.205374932 & 0.161379413 \\
C17 & 0.193035707 & 0.174742738 \\
C18 & 0.219125317 & 0.148596451 \\
C19 & 0.171739744 & 0.200391822 \\
C20 & 0.186934402 & 0.175183698 \\
\hline
\end{tabular}

Table 5. Ranking of healthcare companies in all sectors

\begin{tabular}{cccc}
\hline Code & Companies & Relative closeness to the ideal solution, $s_{i w}$ & Rank \\
\hline C19 & TOP GLOVE CORP & 0.538497242 & 1 \\
C6 & IHH HEALTHCARE & 0.53435146 & 2 \\
C7 & KOSSAN RUBBER & 0.531975448 & 3 \\
C8 & KOTRA INDUSTRIES BHD & 0.498834043 & 4 \\
C3 & CAREPLUS GROUP B & 0.484536364 & 5 \\
C20 & YSP SOUTHEAST ASIA & 0.483775039 & 6 \\
C17 & SUPERMAX CORP BHD & 0.475130449 & 7 \\
C4 & DUOPHAMA & 0.474554753 & 8 \\
C15 & PHARMANIAGA BERHAD & 0.464879211 & 9 \\
C5 & HARTALEGA HOLDINGS & 0.464251266 & 10 \\
C14 & OPTIMAX & 0.461470651 & 11 \\
C9 & KPJ HEALTHCARE BHD & 0.459997226 & 12 \\
C2 & APEX HEALTHCARE BHD & 0.446142644 & 13 \\
C16 & SMILELINK HEALTH & 0.440020452 & 14 \\
C13 & NOVA PHARMA SOL & 0.436708911 & 15 \\
C10 & LKL INTERNATIONAL & 0.429574188 & 17 \\
C12 & MALAYSIAN GENOMICS & 0.424649372 & 18 \\
C18 & TMC LIFE SCIENCES & 0.404100231 & 19 \\
C11 & LYC HEALTHCARE BHD & 0.390351432 & 20 \\
C1 & ADVENTA BHD & 0.365526069 & \\
\hline
\end{tabular}


Table 6. Companies ranking in the healthcare equipment sector

\begin{tabular}{cccc}
\hline Code & Companies & Relative closeness to the ideal solution, $s_{i w}$ & Rank \\
\hline C19 & TOP GLOVE CORP & 0.595250172 & 1 \\
C7 & KOSSAN RUBBER & 0.548957974 & 2 \\
C5 & HARTALEGA HOLDINGS & 0.515778735 & 3 \\
C17 & SUPERMAX CORP BHD & 0.498682853 & 4 \\
C3 & CAREPLUS GROUP B & 0.471696299 & 5 \\
C10 & LKL INTERNATIONAL & 0.462888102 & 6 \\
C12 & MALAYSIAN GENOMICS & 0.422282041 & 7 \\
C1 & ADVENTA BHD & 0.369262634 & 8 \\
\hline
\end{tabular}

Table 7. Companies ranking in the healthcare provider sector

\begin{tabular}{cccc}
\hline Code & Companies & Relative closeness to the ideal solution, $s_{i w}$ & Rank \\
\hline C6 & IHH HEALTHCARE & 0.695754977 & 1 \\
C14 & KPJ HEALTHCARE BHD & 0.648451308 & 2 \\
C9 & OPTIMAX & 0.619869593 & 3 \\
C18 & SMILELINK HEALTH & 0.552866384 & 4 \\
C16 & TMC LIFE SCIENCES & 0.477479238 & 5 \\
C11 & LYC HEALTHCARE BHD & 0.187713071 & 6 \\
\hline
\end{tabular}

Table 8. Companies ranking in the healthcare pharmaceutical sector

\begin{tabular}{cccc}
\hline Code & Companies & Relative closeness to the ideal solution, $s_{i w}$ & Rank \\
\hline C8 & KOTRA INDUSTRIES BHD & 0.641227737 & 1 \\
C4 & DUOPHAMA & 0.610813443 & 2 \\
C20 & YSP SOUTHEAST ASIA & 0.527174627 & 3 \\
C15 & PHARMANIAGA BERHAD & 0.519468737 & 4 \\
C2 & APEX HEALTHCARE BHD & 0.480733053 & 5 \\
C13 & NOVA PHARMA SOL & 0.377588248 & 6 \\
\hline
\end{tabular}

\section{CONCLUSION}

In conclusion, this article has fulfilled its objective to evaluate 20 Malaysian healthcare companies using the TOPSIS multi-criteria decision-making method. The findings from this paper can be used to assist investors in making investment decisions alongside other techniques. This paper, which utilizes financial ratios as the criteria, has managed to evaluate the companies' financial performances and ranked them accordingly. It is found that the top five companies from the overall three sub-sectors in the healthcare industry (Top Glove Corp, IHH healthcare, Kossan Rubber, Kotra Industries Bhd and Careplus Group) also stood up as the top two companies in their respective sub-sectors. One of the profound factors is that these top companies also posit themselves as leading players in the healthcare industry. It is recommended that the study is conducted in different industries in future research by utilizing more advanced techniques and methodology. Further studies should also consider confirming the ranking results using TOPSIS techniques with a different set of methodology. By doing so, the result's robustness can be obtained.

\section{ACKNOWLEDGEMENTS}

The authors would like to thank Universiti Teknologi MARA for their facilities and continuous support.

\section{REFERENCES}

[1] C.-L. Hwang and K. Yoon, "Methods for Multiple Attribute Decision Making," in Multiple Attribute Decision Making, 1981, pp. 58-191, doi: 10.1007/978-3-642-48318-9_3.

[2] Y. Almoghathawi, K. Barker, C. M. Rocco, and C. D. Nicholson, "A multi-criteria decision analysis approach for importance identification and ranking of network components," Reliability Engineering and System Safety, vol. 158, pp. 142-151, Feb. 2017, doi: 10.1016/j.ress.2016.10.007.

[3] N. Chen, L. Chen, Y. Ma, and A. Chen, "Regional disaster risk assessment of china based on self-organizing map: Clustering, visualization and ranking," International Journal of Disaster Risk Reduction, pp. 196-206, Feb. 2019, doi: 10.1016/j.ijdrr.2018.10.005.

[4] M. Jupri and R. Sarno, "Data mining, fuzzy AHP and TOPSIS for optimizing taxpayer supervision," Indonesian Journal of Electrical Engineering and Computer Science, vol. 18, no. 1, pp. 75-87, Apr. 2019, doi: 10.11591/ijeecs.v18.i1.pp75-87.

[5] L. Ferreira, D. Borenstein, and E. Santi, "Hybrid fuzzy MADM ranking procedure for better alternative discrimination," Engineering Applications of Artificial Intelligence, vol. 50, pp. 71-82, Apr. 2016, doi: 10.1016/j.engappai.2015.12.012.

[6] M. Behzadian, S. K. Otaghsara, M. Yazdani, and J. Ignatius, "A state-of the-art survey of TOPSIS applications," Expert Systems with Applications, vol. 39, no. 17, pp. 13051-13069, Dec. 2012, doi: 10.1016/j.eswa.2012.05.056.

[7] N. A. Fahami, F. W. Azhar, Z. H. A. Rahim, and H. A. Karim, "Fuzzy logic application in evaluating financial performance: a case study of services sector in Malaysia,” Australian Journal of Business and Economic Studies, vol. 1, no. 1, pp. 69-73, 2015. 
[8] T. M. Wasara and F. Ganda, "The relationship between corporate sustainability disclosure and firm financial performance in Johannesburg Stock Exchange (JSE) listed mining companies,” Sustainability (Switzerland), vol. 11, no. 16, p. 4496, Aug. 2019, doi: $10.3390 / \mathrm{su} 11164496$.

[9] A. Hamdan, R. Khamis, M. Anasweh, M. Al-Hashimi, and A. Razzaque, "IT governance and firm performance: empirical study from Saudi Arabia," SAGE Open, vol. 9, no. 2, p. 215824401984372, Apr. 2019, doi: 10.1177/2158244019843721.

[10] K. Raed, "Dividend policy and companies Financial Performance," Journal of Asian Finance, Economics and Business, vol. 7, no. 10, pp. 531-542, Oct. 2020, doi: 10.13106/jafeb.2020.vol7.no10.531.

[11] C. M. Feng and R. T. Wang, "Performance evaluation for airlines including the consideration of financial ratios," Journal of Air Transport Management, vol. 6, no. 3, pp. 133-142, Jul. 2000, doi: 10.1016/S0969-6997(00)00003-X.

[12] N. Balc1, "Financial performance analysis with topsis technique: a case study of public university hospitals in Turkey," Yönetim ve Ekonomi Araştırmaları Dergisi, pp. 155-176, Dec. 2017, doi: 10.11611/yead.373456.

[13] L. W. Hoe, L. W. Siew, L. K. Fai, A. L. J. Xin, and L. P. Fun, "An empirical evaluation on the performance of food service industry in Malaysia with TOPSIS model," Journal of Physics: Conference Series, vol. 1706, no. 1, Dec. 2020, p. 012172, doi: $10.1088 / 1742-6596 / 1706 / 1 / 012172$.

[14] Z. H. Abd Rahim, N. A. Fahami, F. W. Azhar, H. Abd Karim, and S. K. N. Abdul Rahim, "Application of TOPSIS analysis method in financial performance evaluation: A case study of construction sector in Malaysia," Advances in Business Research International Journal, vol. 6, no. 1, p. 11, May 2020, doi: 10.24191/abrij.v6i1.9934.

[15] L. W. Hoe, Y. H. Beng, L. W. Siew, and C. J. Wai, "Analysis on the performance of technology companies with Z-score model," Bulletin of Electrical Engineering and Informatics, vol. 7, no. 4, pp. 633-639, Dec. 2018, doi: 10.11591/eei.v7i4.1353.

[16] H. Deng, C. H. Yeh, and R. J. Willis, "Inter-company comparison using modified TOPSIS with objective weights," Computers and Operations Research, vol. 27, no. 10, pp. 963-973, Sep. 2000, doi: 10.1016/S0305-0548(99)00069-6.

[17] S. B. Yildiz, "Performance analysis of Turkey's participation and conventional indices using TOPSIS method," Journal of Islamic Accounting and Business Research, vol. 11, no. 7, pp. 1403-1416, Jan. 2020, doi: 10.1108/JIABR-08-2018-0123.

[18] H. Dinçer, S. Yüksel, and Z. Adalı, "Determining the effects of monetary policies on capital markets of the emerging economies: An evidence from E7 countries," in The Impacts of Monetary Policy in the 21st Century: Perspectives from Emerging Economies, Emerald Publishing Limited, 2019, pp. 3-16.

[19] P. Wanke, M. A. K. Azad, and C. P. Barros, "Efficiency factors in OECD banks: A ten-year analysis," Expert Systems with Applications, vol. 64, pp. 208-227, Dec. 2016, doi: 10.1016/j.eswa.2016.07.020.

[20] K. Mandic, B. Delibasic, S. Knezevic, and S. Benkovic, "Analysis of the financial parameters of Serbian banks through the application of the fuzzy AHP and TOPSIS methods," Economic Modelling, vol. 43, pp. 30-37, Dec. 2014, doi: 10.1016/j.econmod.2014.07.036.

[21] J. Reig-Mullor, J. M. Brotons-Martinez, and M. E. Sansalvador-Selles, "A novel approach to improve the bank ranking process: An empirical study in Spain,” Journal of Intelligent and Fuzzy Systems, vol. 38, no. 5, pp. 5323-5331, May 2020, doi: 10.3233/JIFS-179626.

[22] J. Hussain, K. Zhou, S. Guo, and A. Khan, "Investment risk and natural resource potential in 'Belt \& Road Initiative' countries: A multi-criteria decision-making approach," Science of the Total Environment, vol. 723, p. 137981, Jun. 2020, doi: 10.1016/j.scitotenv.2020.137981.

[23] L. W. Hoe, L. W. Siew, and L. K. Fai, "Performance analysis on telecommunication companies in Malaysia with TOPSIS model," Indonesian Journal of Electrical Engineering and Computer Science, vol. 13, no. 2, pp. 744-751, Feb. 2019, doi: 10.11591/ijeecs.v13.i2.pp744-751.

[24] M. M. Alam, H. Wei, and A. N. M. Wahid, "COVID-19 outbreak and sectoral performance of the Australian stock market: An event study analysis," Australian Economic Papers, vol. 60, no. 3, pp. 482-495, Sep. 2021, doi: 10.1111/1467-8454.12215.

[25] K. Yong-Ming Lee, M. Jais, and C.-W. Chan, "Impact of Covid-19: Evidence from Malaysian Stock Market," International Journal of Business and Society, vol. 21, no. 2, pp. 607-628, Jul. 2020, doi: 10.33736/ijbs.3274.2020.

\section{BIOGRAPHIES OF AUTHORS}
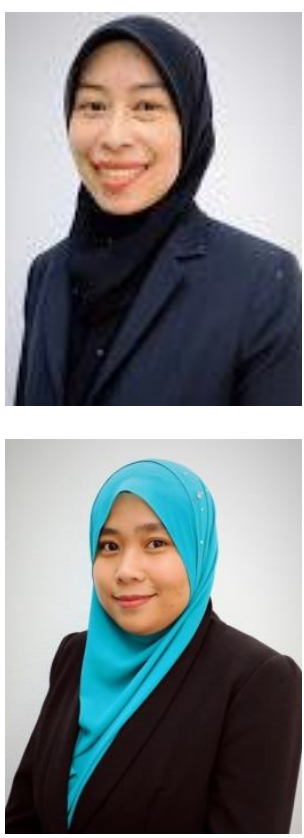

Farah Waheeda Azhar (iD 81 SC P received her Bachelor's Degree in Mathematics and MSc of Science in Mathematics from Universiti Teknologi MARA (UiTM) and Universiti Kebangsaan Malaysia in 2008 and 2010, respectively. She is now a Lecturer at the Faculty of Computer and Mathematical Sciences, Universiti Teknologi MARA (UiTM) Perak Campus. Her main research areas lie in the area of Mathematics. She can be contacted at email: farah154@uitm.edu.my.

Zati Halwani Abd Rahim (D) S8 SC P is currently a lecturer at the Faculty of Computer and Mathematical Sciences, Universiti Teknologi MARA (UiTM) Perak Campus. She completed her MSc of Science in Mathematics from Universiti Kebangsaan Malaysia. She earned a Bachelor's Degree in Management Mathematics and a Diploma in Quantitative Science at Universiti Teknologi MARA (UiTM). Her area of interest is Mathematics. She can be contacted at email: zati6141@uitm.edu.my. 

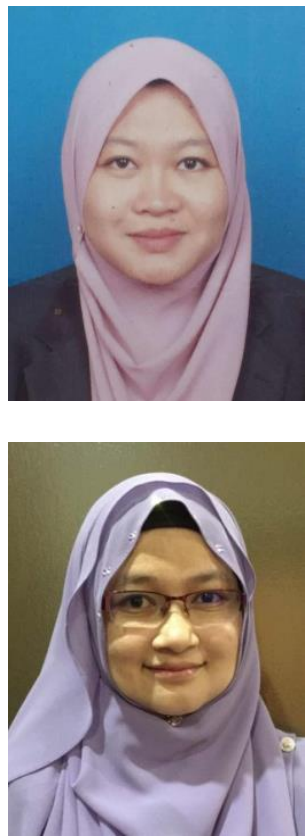

Siti Khatijah Nor Abdul Rahim (DD SC P is a Senior Lecturer at the Faculty of Computer and Mathematical Sciences, Universiti Teknologi MARA, Shah Alam Selangor. She gained her Ph.D. in Computer Science from the University of Nottingham in 2015. Before that, she received her Bachelor's Degree in Computer Science and MSc of Science (Computer Science) from Universiti Sains Malaysia (USM), Penang, Malaysia, in 2001 and 2003, respectively. Her main research areas lie in the area of Computational Intelligence, Granular Computing, Scheduling, Optimization, and Applied Computing. She can be contacted at email: sitik781@uitm.edu.my.

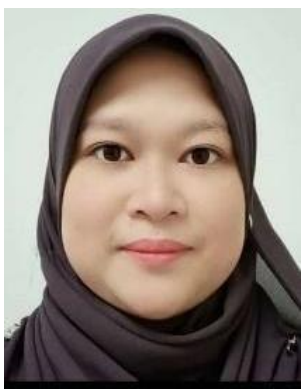

Hilwana Abd Karim (D) SC S $\mathrm{P}$ is a senior lecturer at the Faculty of Business and Management, University Technology MARA Negeri Sembilan Branch, Seremban campus. She obtained a Master in Business Administration (Organization Management) from Universiti Kebangsaan Malaysia in 2010 and a Bachelor (Hons) of Business Administration (International Business) from University Technology MARA in 2008. Her research areas are entrepreneurship, Organization Management and Human resources. She can be contacted at email: hilwana250@uitm.edu.my. 